\title{
Methodological approach to risk-assignment for joint ventures in energy industry
}

\author{
Anna Dudnik ${ }^{1, *}$ \\ ${ }^{1}$ Plekhanov Russian University of Economics, 115093, 36, Stremaynniy pereulok, Moscow, Russia
}

\begin{abstract}
The article provides guidance about risk allotment regarding to joint ventures operating in energy industry. Energy industry has been overwhelmed by risk, in compare to other branches. To diminish the chance of failure on international partnership, risk management techniques should be based on methodological principals. The paper presents outlook to risk in response to the stage of a joint project. The methodological approach is structured in accordance with risk group hierarchy received with Delphi evaluation method. Thus, joint ventures parties are allowed to complete an effective review in order to implement risk reduction actions.
\end{abstract}

\section{Introduction}

A joint venture is still highly used business model in energy industry worldwide. HIS Consulting data demonstrates the prevalence of joint ventures in oil and gas sector (Chart 1) [1]. As it is evident from the chart, the overall production by joint ventures within International energy companies is estimated in more then 2 millions barrels of oil equivalent per day.
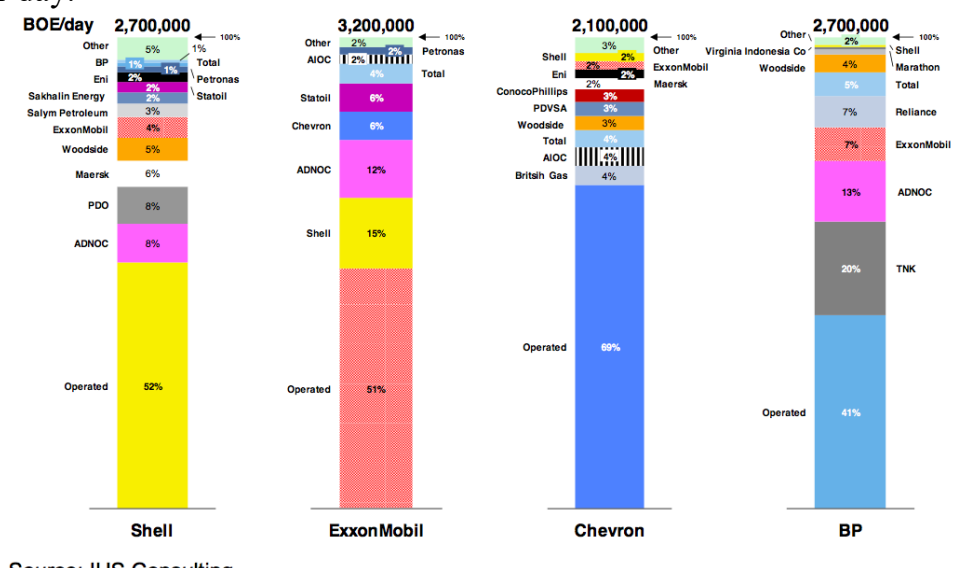

Source: IHS Consulting

Fig. 1. Illustration of JV incidence in oil and gas industry

\footnotetext{
* Corresponding author: annetdd@gmail.com
} 
Joint venture is a form of economic cooperation of international actors which combine their resources to achieve the mutual objectives. Joint ventures are considered to rise profitableness of energy industry by decreasing competition in markets[2]. That is therefore the particularities of the branch that make joint entrepreneurship so attractive in energy industry. The partners combine their strongest individual components, such as the right to use national resources of recipient country and investing technologies for energy resources exploration. In international practice relatively large joint venture set up in industrial sector, while smaller scale joint venture - in resourced based domains. According to statistical information two third of the joint ventures in countries with high level of risk conduct activities in the commodity sector, and three quarters of the joint ventures operate in country with low risk level [3].

The conception of attracting foreign capital in energy industry through creating a joint venture with foreign participant directly depends on the degree of urgency of the targets. There is no need to enter into joint venture agreement for short-term projects (up to 3 years) on, for example, inactive wells restoration. In this case, it is easier to find a foreign partner among small or medium-size oil firms, equipment suppliers, financial institutions.

For the project with up to 5 years timeframe the priority areas of activity could be development of proven deposits, which are not extracted yet. The company may lack of fund for developing fields, which have already been discovered. Consequently, it would be interested in partnership with large energy firms and consortiums, as well as financial institutions.

The riskiest category for set up a joint venture is long-term projects on prospecting, exploration and development of mineral resources in new fields. The most common types of such joint ventures are:

- Joint ventures on energy resources development

- Joint enterprises providing service facilities

-Ecological joint ventures on recovery and oil waste treatment, disaster recovery of accidental oil spill and etc.

For certain countries with the commodity-dependent economy energy industry is the main source of budget revenues. For private sector investors it is so attractive due to prospects for profitability. On the whole, however, the interests of each alleged participant of a joint venture are widely divergent.

Table 1. Interests of international joint venture participants

\begin{tabular}{|c|l|}
\hline Risks & \multicolumn{1}{c|}{ Interests } \\
\hline $\begin{array}{c}\text { Foreign } \\
\text { party }\end{array}$ & $\begin{array}{l}\text { Political risks reduction; } \\
\text { Decrease of adninistrative barierres ; } \\
\text { Access to national resources; } \\
\text { Export to the local market; } \\
\text { Provision of local labour force }\end{array}$ \\
\hline & $\begin{array}{l}\text { Generating additional income from state assets; } \\
\text { Risk mitigation; } \\
\text { Create competitive environment; } \\
\text { Fiscal revenue increase; } \\
\text { Modernisation of infractructure; } \\
\text { Contributing to the social effictivness; } \\
\text { Regional development; } \\
\text { Improving the environmental situation. }\end{array}$ \\
\hline Local & Engaging budgetary funds; \\
Rartner & Risk reduction; \\
\hline
\end{tabular}




\begin{tabular}{|l|l|}
\hline & $\begin{array}{l}\text { Infrustructure upgrading; } \\
\text { Tax benefits }\end{array}$ \\
\hline
\end{tabular}

It may be concluded, that risk reduction is the main mutual objective ground for a joint venture set up. Risks associated with a joint venture in energy industry are crucial and distinct from other type of joint ventures. Meanwhile, the classical approach to riskmanagement, which is used in international energy companies, is not entirely appropriate for joint venture business model. For the time being, there is not wholly integrated system of identification and classification of risks that the energy joint venture faces [4].

\section{Materials and methods}

The object of the paper is to develop a methodological approach for risk assignment in a joint venture.

The subject of the research is risks occurring in joint ventures within energy industry.

The main methods for achieving the research aims and objectives are descriptive methods, methods of expert assessments, comparative methods and associational type of research such as causal-comparative. General logical methods are also used in the study: analysis, synthesis, structural and system analysis of business processes. The author systematized a set of the most significant grouping characteristics that determine risk at every stage of a joint venture that allows to objectively evaluating indicators depending on risk assessment.

The research methodology was divided into three major sections consisting of a literature review, questionnaire survey, and qualitative content analysis.

The study is not focused on possible risk arising mainly in international energy companies that is extremely popular topic for research. The research question was to find an approach for risk assignment refers to joint ventures tailored to energy industry.

\section{Results and discussion}

Energy industry enters the national strategic pillars, thus, state owned enterprises is frequently encountered, they are customarily chosen for partnership as the preferred form of risk reduction. Notwithstanding such an advantage of a join venture, the failure rate is about $40-70 \%$ [5].

It should be mentioned that the energy industry itself is characterized by some features that differentiate it from other industries [6]:

- Significant amount of the joint ventures is attributable to hefty investments demanded in plenty stage of the industry, many oil and gas activities are hold in joint ventures to split the tremendous expenditures.

-The ineluctable political factor. The energy industry has a strong impact on ongoing global economic tendency and vice versa. The oil and gas business is seen as highly unstable owing to multiple unforeseeable causes, predominantly the imposing political events parallel to their consequences and the recurrent price volatility. The ownership of energy resources has been the primary reasons of border disputes and international conflicts.

-The complex price determination. Firstly, the factors affecting oil and gas prices dynamics include both micro and macroeconomics. Secondly, notwithstanding the fact that technological revolution develops techniques for this industry, this enhanced production put its weight on prices. 
-Environmental risks. World energy demand is continuing to mount. In 2018 it rose by $2,3 \%$ [7]. Thus, the industry influences the local environment and population where activities take place. Energy firms have to reduce the negative effects liaise with their operations.

From the previous studies the main challenges of joint ventures are political risks, cultural adaptation and economics [8]. Political risk is highlighted as essential by Adnan H., Bakar Z.A., Banford J. Such authors as Ding D., Beamish P., Abd-Karim S., Kublin M. emphasized financial issues. Matthew C., Atkins M. and others agreed with huge impact of cultural risks on a joint venture. It is not a comprehensive list of researches, but the mentioned authors contributed a lot to joint venture's analysis at different times

The field of oil and gas has witnesses some major risks which are specific for this industry. The companies of energy industry is striking example of the fact, that the weight of risk changes dramatically at every stage of the partnership. Especially heightened risks should be addressed in the transition from one stage to another.

At the geological prospecting stage the most important risks are deemed to be geological and legal. During the exploration the risks of financial and operational are mostly highlighted. The phase of construction of on-field facilities, its exploration is potentially highly exposed to risks.

Cooperation with a local partner provides a foreigner partner with specific knowledge about the regional market, its infrastructure and local production facilities, product quality, distribution channels, workforce and al. Simultaneously, the risk of ineffective communication is rising on the ground of cultural differences, different mentalities. The indirect impact of cultural differences on the enterprise performance should be noted, particularly on the level of trust between partners. Nonetheless, the resolving is rather difficult.

Twofold risk mitigation has been observed in establishing private-public partnership in host country. Risk allocation between the participants in uneven and there is a number of characteristics:

-Unequal responsibility sharing;

Responsibility for project implementation lies generally with the private partner, while the public sector, that is more interested in national economic development and in socially significant effect achievement, is charged with output final product or service delivered.

-Different capacity level of managing the risk;

Possibilities of each partner for risk-management vary widely which affects project expenditure. Efficacious risk allocation will contribute to cost reduction compare to the independent activity of each partner.

-Limited financial capacity

Financial resources of each party vary considerably, that implies that ability to bear the risk of the partners is limited. Pooling of financial resources under public-private partnership will ensure the sustainability of the project [9]. It is apparent, that for joint venture businesses model the partner with better any particular resources should cover the risk [10].

Risk assignment aims at ranking with probability of event occurrence and with extend of possible damage. For each chosen risk category the criterion on measurement and evolution of risk should be defined [11]. However, in practice selection of suitable indicators is appeared to be tremendous complication for a variety of reasons:

-The multiplicity of the process in joint ventures can be characterized by many criteria and such an amount impedes the methods for calculation of indicators;

-Even the most detailed method cannot estimate risk comprehensively;

-All indicators interact under certain circumstances of surrounding validity. They are subject to influence by socioeconomic, political, informational, scientific-technical 
and other parameters. In this respect, the transformation of even one leads to change of these factors themselves partly, its significance and exposure on joint project.

All this does not allow building an unambiguous methodological approach of risk measurement indicators. The key concept of creating this scheme is to integrate relative allocation for effective management the risk exposures in the branch.

The algorithm of the presented methodological approach (Tab.2) is the following: 1.A project is subdivided into 4 stages corresponding typical lifecycle in energy industry. 2.For each phase the significance of the certain risk groups was estimated with Delphi approach and ranked hierarchically.

3. The possible risk allocation between the parties of joint venture in public-private partnership is illustrated.

4.Likelihood (Lol) of occurrence of each risk area was estimated, which allows to choose relevant risk response measures.

Table 2. An aggregation of risk-assignment.

\begin{tabular}{|c|c|c|c|c|c|}
\hline \multirow{2}{*}{$\begin{array}{l}\text { Phase of JV } \\
\text { project }\end{array}$} & \multirow{2}{*}{$\begin{array}{l}\text { Risk } \\
\text { hierarchy }\end{array}$} & \multirow[t]{2}{*}{ Lol } & \multicolumn{3}{|c|}{ Risk allocation } \\
\hline & & & Risk group & State & $\begin{array}{l}\text { Private } \\
\text { partner }\end{array}$ \\
\hline \multirow{3}{*}{ Preparatory } & 1. Country & High & \multirow{17}{*}{$\begin{array}{l}\text { Country risks: } \\
\text {-Expropriation } \\
\text {-Global amendment in legislation } \\
\text {-Specific (peculiar) in fiscal system } \\
\text {-Political events } \\
\text { Financial risks: } \\
\text {-Cost overrun } \\
\text { - Insolvency of conterparty } \\
\text {-Inflation } \\
\text {-Currency fluctuation } \\
\text {-Market interest rate change } \\
\text {-Transfer risks: failure to } \\
\text { implement international } \\
\text { transactions } \\
\text { Operational risk: } \\
\text {-Administrative barriers } \\
\text {-Infrastructure and logistic risks } \\
\text {-Climate change and environmental } \\
\text { (ecological) risks } \\
\text {-Force majeure } \\
\text {-Certification system development } \\
\text {-Technical challenges } \\
\text {-Violation in supply } \\
\text {-Strategic risks } \\
\text {-Human resource risks } \\
\text { Cultural risks: } \\
\text {-Differences in national cultures } \\
\text {-Differences in corporate cultures }\end{array}$} & \multirow{4}{*}{$\begin{array}{l}\text { V } \\
\text { V } \\
\text { V }\end{array}$} & \multirow{4}{*}{ V } \\
\hline & 2. Cultural & High & & & \\
\hline & 3. Financial & High & & & \\
\hline \multirow{5}{*}{$\begin{array}{l}\text { Upstream } \\
\text { exploration }\end{array}$} & 1.Ecological & $\begin{array}{l}\text { Very } \\
\text { high }\end{array}$ & & & \\
\hline & 2.Operational & $\begin{array}{l}\text { Very } \\
\text { high }\end{array}$ & & & $\begin{array}{l}\mathrm{V} \\
\mathrm{v}\end{array}$ \\
\hline & 3.Financial & $\begin{array}{l}\text { Very } \\
\text { High }\end{array}$ & & \multirow{2}{*}{$\begin{array}{l}\mathrm{V} \\
\mathrm{V}\end{array}$} & $\begin{array}{l}\mathrm{v} \\
\mathrm{v}\end{array}$ \\
\hline & 4.Country & Medium & & & \\
\hline & 5.Cultural & Medium & & \multirow[b]{3}{*}{$\mathrm{v}$} & \\
\hline \multirow{5}{*}{$\begin{array}{c}\text { Downstream } \\
\text { activities }\end{array}$} & 1.Financial & Medium & & & \\
\hline & 1.Operational & $\begin{array}{l}\text { Very } \\
\text { High }\end{array}$ & & & \\
\hline & 2.Ecological & Medium & & \multirow{3}{*}{$\mathrm{v}$} & \multirow[b]{2}{*}{$\begin{array}{l}\text { V } \\
\text { V }\end{array}$} \\
\hline & 3.Country & Low & & & \\
\hline & 4.Cultural & Low & & & V \\
\hline \multirow{4}{*}{ Closure } & 1.Operational & High & & \multirow{4}{*}{$\mathrm{V}$} & \multirow{4}{*}{$\begin{array}{l}\mathrm{V} \\
\mathrm{V} \\
\mathrm{V} \\
\mathrm{V} \\
\mathrm{V}\end{array}$} \\
\hline & 2.Country & Medium & & & \\
\hline & 3.Ecological & $\begin{array}{l}\text { Very } \\
\text { high }\end{array}$ & & & \\
\hline & 4.Cultural & Low & & & \\
\hline
\end{tabular}

\section{Conclusion}

The risk assignment in collaborative ventures is much more complex issue than preceding studies have implied. In addition to theoretical inferences of this paper, corporate insight for the management of international joint ventures can be drawn.

The paper identifies the framework for risk allocation regarding to joint ventures operating in energy industry. The methodological scheme presents approach to risk in term 
of four main stages of a joint venture: preparatory, upstream, downstream, closure. The risks affecting the joint venture performance throughout different stages of the project are quite differential. Due to it, the methodological approach is formed in compliance with the risk group hierarchy for which expert evaluation method was chosen.

Application of the introduced approach allows to carry out a comprehensive analytical assignment of potential risk arise. It is recommended that the joint ventures assign priorities all risk areas and implement proper resources for the management of these risks.

\section{References}

1. M. Jelinek, J. Petit, The Joint Venture Handbook (IHS Consulting, 2018)

2. T. Sammut-Bonnici, D. Channon, Joint ventures. In Wiley Encyclopedia of management, 12, (2015)

3. S. Janakiramanan, S. Lamba Asjeet International joint ventures and political risk. International business research conference, Research Collection Lee Kong Chain School of Business (Melbourne, 2004)

4. A. A. Marenyuk, A. E. Tasmukhanova, Upravlenie economicheskimi sistememi, 5, 512 (2017)

5. U. Ott, D. Williams, J. Saker, L. Staley, Journal of innovation and knowledge, 4 (3), 202-210 (2019)

6. A. Hammoutene, A. Zanoun, La Revue des Sciences Commerciales, 15 (2), 125-145 (2016)

7. Global energy demand rose by 2018 , IEA, (2019)

8. N. Romeli, F. Halid, F. Ismail, Saifuza Abd Shukok A. Economic challenges in infrastructure projects: towards contractor's quality of life. Procedia - Social and behavior sciences, 234, 19-27 (2016)

9. P. E. Klimov, Risk allocation PPProjects, Upravlenie economicheskimi sistememi, 8, (2012)

10. T. M. Mataev, Rossiyskoe predprinimatelstvo. 13 (3), 4-10 (2012)

11. A. V. Aleshin, Upravlenie riskami: znaniya i opit proshlyh proektov. Upravlenie proektami i programmami, 2, 13 (2010) (In Russ.) 